\title{
PROBLEMATIKA HUKUM AKTA HIBAH ATAS TANAH YANG TIDAK SAH KARENA MELEBIHI BAGIAN TERKECIL AHLI WARIS
}

\author{
Ratnasari $^{*}$, Akhmad Khisni $^{* *}$ \\ * Mahasiswa Program Magister (S2) Kenotariatan Fakultas Hukum UNISSULA, email : ratnasari28cok@yahoo.com \\ ${ }^{* *}$ Dosen Fakultas Hukum UNISSULA
}

\begin{abstract}
A grant is a legal act of transfer of ownership that is deliberately given to another party. In Article 1682 of Civil Code states that the implementation of the grant is done by using an authentic deed. The finding of this research on the verdict of Klaten District Court no. 8 / Pdt. G / 2001 / PN.KIt, where the land grant with Grant Deed no. 387 / DLG / 23/1999 and Grant Deed no. 388 / DLG / 23/1999 dated 30 August 1999 which has been made by defendant I (Land grantee) is declared null and void because it is illegal (legal defect) and has no legal power to be used as evidence of land grant rights. The conclusion in this research is the consideration of the judge in civil suit case with case No.8 / PDT.G / 2001 / PN. Klt constituted by the Civil Code (BW) which states the Grant Deed No 387 / DLG / 23/1999 and the Grant Deed No. 388 / DLG / 23/1999 shall be declared to have no legal force and shall be void by law because they have no material evidentiary power.
\end{abstract}

Keywords : Legal Problems, Authentic deed, The heir's minimum right

\section{PENDAHULUAN}

Hukum berkaitan dengan kaidah norma atau aturan yang ada dalam masyarakat dan mencerminkan nilai-nilai yang ada dalam masyarakat. Bahkan umumnya ada pendapat yang menyatakan hukum yang baik seperti yang dicita-citakan oleh masyarakat sosial, maka diperlukan kaidah-kaidah (hukum) sebagai alatnya. Kaidah-kaidah tersebut berupa aturan hukum yang disertai dengan sanksi-sanksi yang tegas. Ada suatu keadaan yang tidak dapat dihindari, sehingga timbul suatu ketegangan karena terdapat perbedaan kepentingan.

Perbedaan tersebut dapat menimbulkan perselisihan atau ketegangan satu dengan yang lainnya. Bahkan dapat terjadi di dalam suatu keluarga. Pola kehidupan manusia berawal dari keluarga. Keluarga dapat memberikan suatu ajaran yang baik dalam hidup bermasyarakat. Keluarga terdiri dari orang tua dan anak-anaknya, maka anak-anaknya pun dapat menjadi bagian dari masyarakat yang baik pula, sebab dalam satu keluarga perselisihan atau perbedaan pendapat kemungkinan dapat terjadi. Permasalahan yang sering timbul adalah mengenai peralihan harta dari orang tua kepada anak-anaknya yang biasanya dalam bentuk hibah.

Permasalahan dalam tulisan ini yakni bagaimana problematika hukum akta hibah atas tanah di Pengadilan Negeri Klaten, apakah akta hibah atas tanah memiliki nilai keabsahan (tidak melebihi bagian terkecil ahli waris) yang dibuktikan melalui proses pembuktian di Pengadilan, dan apakah hasil putusan PN Klaten No.8/Pdt. G/2001/PN.klt dapat membuktikan keabsahan Akta Hibah atas Tanah yang dibuat oleh PPAT dengan mengacu pada hukum waris berdasarkan hukum KUH Perdata.

\section{METODE PENELITIAN}

Metode penelitian yang akan penulis gunakan dalam penelitian ini adalah yuridis normatif, yakni dengan menelusuri dan mengkaji bahan-bahan kepustakaan yang berhubungan dengan permasalahan. Penelitian ini dilakukan untuk mendapatkan gambaran tentang problematika hukum yang terjadi dari proses penghibahan tanah dan bagaimana kedudukan hukum akta hibah yang dibuat secara normative dan proses pembuktian di Pengadilan 
Penelitian ini bersifat deskriptif yang bertujuan menguraikan fakta guna memperoleh gambaran secara menyeluruh, permasalahan yang muncul, mengkaji dan merumuskan fakta hukum untuk mengetahui bagaimana kekuatan hukum akta hibah dapat dibuktikan keabsahannya di pengadilan. Jenis data adalah data Primer merupakan data yang didapat dari lapangan, data diperoleh dari responden. Data Sekunder yaitu data yang diperoleh dari atau berasal dari bahan kepustakaan, data sekunder yang dikumpulkan pada penelitian ini antara lain bahan hukum primer, bahan hukum sekunder dan bahan hukum tersier. Bahan Hukum Sekunder adalah bahan hukum yang bukan berbentuk norma hukum, namun berupa pendapat para ahli, bahan ini didapat dari literature atau buku-buku hukum, majalah, koran, internet, karya tulis sarjana-sarjana baik berupa skripsi, tesis maupun desertasi.

Teknik Analisa diperoleh dari studi dokumen dan studi lapangan dan dianalisis secara kualitatif, kemudian disusun secara sistematis agar diperoleh kejelasan dari permasalahan kemudian di tarik kesimpulan secara dedukatif, yaitu dari hal yang bersifat umum menjadi hal yang bersifat khusus.

\section{HASIL PENELITIAN DAN PEMBAHASAN}

Problematika hukum dapat berkaitan dengan sengketa atau tindakan perlawanan antara masingmasing pihak yang disebabkan karena peristiwa atau perbuatan hukum yang mengakibatkan perselisihan paham atau pendapat yang dapat mengakibatkan peluang untuk kerugian baik secara materiil maupun non materiil atas perbuatan hukum. Penelitian ini berdasar pada kasus perdata di Pengadilan Negeri Klaten Jawa Tengah yang telah menjadi Putusan PN No. 8/Pdt.G/2001/PN.klt tentang pembatalan Akta Hibah No. 387/DLG/23/1999. Penelitian ini bertujuan untuk mengamati dan mengkaji secara yuridis normatif tentang peristiwa pengalihan hak atas tanah sawah dari pihak pemberi hibah kepada pihak penerima hibah atas benda yang tidak bergerak dalam hal ini tanah sawah di daerah kecataman Delanggu Kabupaten Klaten Jawa Tengah. Proses pengalihan hak atas tanah sawah tersebut yang dilakukan dan dibuat oleh PPAT di wilayah kecamatan Delanggu Kabupaten Klaten, diakhiri dengan sengketa yang terjadi antara pihak penerima hibah atas tanah sawah dengan pihak ahli waris atas tanah sawah yang dihibahkan tersebut.

Berdasarkan pada kasus gugatan yang dilakukan oleh pihak ahli waris atas tanah sawah yang menjadi sengketa maka Akta Hibah No. 387/DLG/23/1999 yang telah dibuat oleh pihak PPAT berdasarkan hasil putusan PN No. 8/Pdt.G/2001/ PN.klt. , dinyatakan dibatalkan demi hukum. Hal ini disebabkan karena Akta Hibah yang dibuat tersebut tidak memenuhi bagian terkecil dari ahli waris sehingga secara hukum harus dibatalkan. Hasil Putusan PN Klaten.

Hasil putusan PN Klaten No.8/Pdt. G/2001/ PN.klt dapat membuktikan ketidakabsahan Akta Hibah atas Tanah yang dibuat oleh PPAT dengan mengacu pada hukum waris berdasarkan hukum KUH Perdata. Pembuktian ini melalui proses gelar perkara di persidangan dan proses pertimbangan Hakim Pengadilan Negeri Klaten. Bahwa berdasarkan kekuatan pembuktian yang dimiliki oleh suatu Akta Otentik, menjelaskan bahwa jika salah satu saja dari tiga kekuatan pembuktian Akta PPAT tersebut dalam hal ini kekuatan pembuktian secara materiil tidak terpenuhi, maka Akta Hibah tersebut harus dibatalkan demi hukum karena dinyatakan oleh Pengadilan bahwa Akta tersebut tidak memiliki ke absahan.

\section{KESIMPULAN}

Problematika hukum atas hibah atas tanah yang terjadi di Pengadilan Negeri Klaten atas Akta Hibah No. 387/DLG/23/1999 dan No. 388/DLG/23/1999 tidak memiliki kekuatan materiil. Hal ini disebabkan karena adanya permasalahan dalam proses penghibahan dari pihak pemberi hibah kepada pihak penerima hibah melalui Pejabat yang berwenang, dimana ada bagian dari ahli waris atas tanah sawah yang berhubungan dengan pemberi hibah, merasa dirugikan karena dalam Akta Hibah tersebut tidak mencantumkan bagian yang seharusnya diakui dan diterima oleh pihak ahli waris.

Adalah kejadian tersebut maka muncul permasalahan yang berujung pada gugatan secara materiil kepada pihak penerima hibah. Dalam kasus ini maka timbul sengketa antara penerima hibah dengan pihak ahli waris dari tanah sawah yang harus disetujui oleh pihak ahli waris untuk mendapat bagian dari tanah 
sawah yang dihibahkan. Dengan kondisi tersebut maka Akta Hibah atas tanah yang dibuat oleh PPAT dinyatakan cacat hukum atau tidak sah karena melebihi bagian terkecil dari ahli waris yang seharusnya diterima. Dengan demikian maka Akta Hibah No. 387/DLG/23/1999 dan No. 388/DLG/23/ 1999 tidak memiliki kekuatan materiil dan harus dibatalkan demi hukum.

Hasil putusan PN Klaten No.8/Pdt. G/2001/ PN.klt dapat membuktikan ketidak absahan Akta Hibah atas Tanah yang dibuat oleh PPAT dengan mengacu pada hukum waris berdasarkan hukum KUH Perdata. Pembuktian ini melalui proses gelar perkara di persidangan dan proses pertimbangan Hakim Pengadilan Negeri Klaten. Bahwa berdasarkan kekuatan pembuktian yang dimiliki oleh suatu Akta Otentik, menjelaskan bahwa jika salah satu saja dari tiga kekuatan pembuktian Akta PPAT tersebut dalam hal ini kekuatan pembuktian secara materiil tidak terpenuhi, maka Akta Hibah tersebut harus dibatalkan demi hukum karena dinyatakan oleh Pengadilan bahwa Akta tersebut tidak memiliki ke absahan.

\section{SARAN}

Pihak pejabat yang berwenang dalam membuat perjanjian Akta Hibah yang ditunjuk oleh pihak pemberi hibah untuk dapat lebih memperhatikan ketentuan tentang penghibahan dimana ada bagian dari ahli waris atas tanah sawah yang berhubungan dengan pemberi hibah, yang harus dicantumkan dalam Akta Hibah yang seharusnya diakui dan diterima oleh pihak ahli waris dengan memenuhi semua ketentuan kekuatan pembuktian Akta Hibah sehingga tidak menimbulkan sengketa antara penerima hibah dengan pihak ahli waris yang ada.

Dengan kondisi Akta Hibah yang cacat hukum karena tidak memenuhi bagian terkecil dari para ahli waris, maka peneliti memberikan saran bahwa setiap pembuatan Akta Hibah oleh pejabat PPAT dapat lebih lagi memperhatikan ketentuan dalam KUHPerdata sehingga Akta Hibah tersebut memiliki kekuatan secara hukum.

Berdasarkan hasil putusan PN Klaten No.8/Pdt. G/2001/PN.klt yang membuktikan ketidak absahan Akta Hibah maka peneliti dapat memberikan saran untuk setiap hasil putusan PN agar dapat dipublikasikan secara on line sehingga dapat diakses secara langsung dan mudah bagi masyarakat yang ingin memahami dan belajar tentang kasus sengketa hibah dan memberikan informasi pembelajaran akan kasus sengketa hibah tanah dan dapat menjadi bahan informasi penting untuk pelaksanaan hibah baik barang bergerak maupun barang tidak bergerak.

\section{DAFTAR PUSTAKA}

\section{A. Buku-Buku}

Abdul Ghofur Anshori, Lembaga Kenotariatan Indonesia, Yogyakarta: UII Press, 2010,

Budiono, Kamus Ilmiah Popular Internasional, Surabaya : Alumni, 2007,

Biro Hukum dan Humas Badan Pertanahan Nasional, Peraturan Jabatan Pejabat Pembuat Akta Tanah

Chuzaimah dan HafiznAnshary AZ. (Editor), Problematika Hukum Islam kontemporer III, Cet.3, Jakarta: Pustaka firdaus, 2007.

M. Ali Hasan, Berbagai macam transaksi dalam Islam, Cet.1, Jakarta: PT Raja Grafindo Persada, 2007.

M. Yahya Harahap, 2012, Hukum Acara Perdata, Sinar Grafika, Jakarta

Subekti, 2010, Hukum Pembuktian, Pradnya Paramita, Jakarta.

Sudikno Mertokusumo, Hukum Acara Perdata Indonesia, Yogyakarta: Liberty Yogyakarta, 2008.

Tim Redaksi Fokusmedia, Kompilasi Hukum Islam, Bandung: Fokusmedia, 2007, Cet II, hlm 56

\section{B. Peraturan Perundang-Undangan}

R. Subekti dan R. Tjitrosudibio, Kitab UndangUndang Hukum Perdata.

Syekh Muhammad ibn Qasim al-Ghazzi, Fath al-Qarib al-Mujib, Semarang: Pustaka Alawiyah, t.th

Subekti dan R.Tjitrosudibio, Kitab Undang-Undang Hukum Perdata. 
Teguh Samudera, Hukum Pembuktian dalam Acara Perdata, Jakarta:Alumni, 1992.

Undang-undang Nomor 5 Tahun 1960 tentang Peraturan Dasar Pokok-Pokok Agraria (Lembaran Negara Republik Indonesia Nomor 104 Tahun 1960. Tambahan Lembaran Negara Republik Indonesia Nomor 2043)

Undang-undang Nomor 30 Tahun 2004 tentang Jabatan Notaris (Lembaran Negara RepublikIndonesia Nomor 117 Tahun 2004.
Tambahan Lembaran Negara Republik Indonesia Nomor 4432)

\section{Internet}

https://id.wikipedia.org/Pengadilan, diakses jam 12.00 wib 2 Mei 2017

\section{Wawancara}

Wawancara dengan Ibu Hakim Dian Hermina Sari, SH (Hakim Pembimbing Pengadilan Negeri Klaten) 